\title{
Risk, Illegality and the State in Kalimantan ${ }^{1}$
}

This chapter focuses on one particular group of Madurese migrants, the entrepreneurs who make a living in East Kalimantan, and it concentrates on one specific topic, the ambiguous relationships that some of these entrepreneurs have with police officers and the illegal activities they jointly engage in. These relationships are key to understanding the establishment and survival of Madurese businesses in East Kalimantan. The analysis offers a view of the everyday interactions between police officers and Madurese migrants in East Kalimantan. This chapter does not deal with the Indonesian police or the state in a wider sense but focuses on the relationship between Madurese and the police in local settings. It provides a view of the state and illegality as seen from below by offering an account based on the perspectives of ordinary people, centring on their everyday life experiences. In so doing, the chapter shows how illegal activities are often essential in establishing business at the lower levels of society. Without illegality and social relationships with the police (aparat), life would be considerably more difficult for migrants.

In the previous chapter, I focused on Madurese migrants and entrepreneurs and the strategies they undertake under the threat of ethnic violence. When I was busy with that study, I soon added illegal activities and the relationships that migrants had with police to my research focus. It turned out that to understand the successes, failures and insecurities of Madurese migrant entrepreneurs in East Kalimantan it was also essential to understand their involvement in illicit and illegal activities. As we shall see, my investigations led to the conclusion that illegal activities and the relationships with the police benefit both migrants and the police in Samarinda. The police needs to tolerate a certain level of crime in order to keep criminality under control. Before reaching that conclusion, I will discuss the nature of Madurese businesses in East Kalimantan and their relationship with police officers.

\section{Risky Business}

Engaging in entrepreneurial activities is an inherently risky business, especially for immigrants who are poorly educated and originate from an ethnic

1 This chapter has been modified and rewritten to fit within the context of this book. It is based on a chapter published in Aspinall and Van Klinken in 2011.

C) GERBEN NOOTEBOOM, 2015 | DOI 10.1163/9789004282988_009

This is an open access chapter distributed under the terms of the Creative Commons Attribution- 
group that is unpopular in the recipient society. The obstacles for migrant entrepreneurs are numerous. They range from a lack of cash or credit, limited access to indigenous networks of information and support, and a general lack of insight into and access to local bureaucratic procedures. Discrimination and even threats of ethnic violence can be a problem. For low-skilled migrants, large parts of the host community are inaccessible and the better jobs are already taken and distributed among established groups. Apart from waged labour within the lowest echelons of society, taking up a trade or business is often the only option.

Being part of an ethnic minority group, apart from the disadvantages outlined above, also has the comparative advantage of being sufficiently distant from the local society and its governing norms to make it possible to engage in profitable, but illicit, activities. Hans Dieter Evers describes the trader's dilemma:

...of either being integrated into the moral economy of the host society, and consequently subjugated to the pressure of solidarity and sharing, or, on the other hand, of separating from the host society, facing discrimination but also being able to claim debts, to accumulate capital and to conduct business and trade successfully.

EVERS 1990:11

Elsewhere, Evers emphasizes how traders tend to minimize risk and maximize trust in inter-ethnic relationships through engaging in many kinds of trading and other relationships (Evers and Schrader 1994; Evers and Mehmet 1994:1). Such considerations largely explain why large proportions of many immigrant minority groups over the world are entrepreneurs (Raillon 1994), and that they are often successful, especially in the informal sector.

The success of immigrant entrepreneurs seems to be the result of a combination of factors: their will (and need) to succeed, their strategic use of ethnic trading networks and inter-ethnic trust, their lack of assimilation and their willingness to take up any activity, no matter how dirty, difficult or unacceptable in local society. The last of these factors is behind why immigrant entrepreneurs are regularly reported as being involved in illegality.

This general picture applies to Madurese entrepreneurs in East Kalimantan. In Samarinda, the capital of the province, about $15 \%$ of Madurese migrants are involved in business or trade. Most of these businesses are small, but they offer work to about three-quarters of the approximately 15,000-20,000 Madurese in the city. Some of the early Madurese migrants (who arrived before the 1990s) are now well-off and own land, houses, cars, transport businesses, recycling firms, construction companies, gambling dens and brothels. They earned their 
'fortunes' during the late 1980s and 1990s when the economy of Samarinda was booming as a result of logging and mining. A number of these businesses operate in the twilight zone between legality and illegality. A small number of them combine perfectly legal trade with activities such as theft, cheating, illegal logging or land occupation and running sex and gambling businesses. Many individual Madurese also work as security guards and assistants for the ethnic Chinese businessmen who organize large-scale gambling at malls, discotheques and bars. However, widespread violence against Madurese in other parts of Kalimantan in 1997-2001 damaged the image and self-esteem of Madurese migrants, making them less attractive as guards. ${ }^{2}$ Some Madurese who had formerly worked as guards have started their own businesses, others have retreated into less risky businesses, or are no longer hired.

In the overal field of illegal economic activities in Samarinda, Madurese are only small players. Very few Madurese were involved in the massive illegal logging operations of the late 1990s and early 200os. More recently, Madurese have also been little involved in the corruption associated with government projects, timber and plantation concessions, and with the embezzlement of royalties from mining activities. ${ }^{3}$ Although Samarinda citizens often view criminality as a characteristic trait of the Madurese people, they are in fact no more engaged in illegal activities than other ethnic groups such as the Buginese, Banjarese, Javanese, Torajanese and Butonese.

According to a middle-ranking police officer in Samarinda, the Banjarese and Buginese are currently among the most criminally active ethnic groups in Samarinda. Buginese gangs dominate protection rackets, the lucrative harbour and market areas and large-scale illegal trades of all kinds, while Banjarese gangs are involved in petty crime such as burglary and pickpocketing. As long as criminality remains petty, and mobs of people are themselves able to punish some of the criminals through public lynching, the police seem not overly concerned. ${ }^{4}$ In general, trust in the police in Indonesia is low and 'people feel that lynching makes the streets safer' (Colombijn 2002:302).

2 For an analysis of anti-Madurese violence elsewhere in Kalimantan see: Schiller and Garang 2002; Davidson and Kammen 2002; Peluso 2006; Peluso and Harwell 2001; Van Klinken 2002. I have discussed the loss of self-esteem and its impact in the previous chapter and also in De Jonge and Nooteboom 2006; Nooteboom 2005.

3 For illegal logging in East Kalimantan, see Casson and Obidzinski 2002.

4 In his discussion of public lynching across the country, Freek Colombijn gives several examples of lynching with the police standing by while the mobs act. He concludes: 'The response of the police to mob justice is in general half-hearted [...]. After the fact, however, the police accept the lynching as it is. They never try to investigate the matter' (2002:319). See also Welsh 2008. 
There is much guessing but few hard facts based on research on the relationships between small entrepreneurs, illegal activities and the police in Indonesia. Adopting a micro-perspective, I have followed Madurese entrepreneurs who have been involved in legal as well as illegal activities in East Kalimantan. Some of the illegal activities are deemed acceptable by the police and yield mutual benefits, while others are clearly unacceptable and the police attempt to stamp them out. Also among Madurese themselves, there are different views on what constitutes acceptable behaviour. Further, it turns out that police officers often collaborate with, or help, Madurese in carrying out many illegal activities. Before discussing these activities in detail, I will first elaborate on the research methodology I used and then outline the background and structure of Madurese migration and entrepreneurship in East Kalimantan.

\section{Researching Illegality}

Studying the relationships between police and migrants in the context of illegality is not easy. By its nature, illegality concerns covert activities, sensitive topics, uneasy relationships, distrust and a shared interest in secrecy by all the actors involved. Both migrant groups and police networks are difficult to penetrate. Access to information and sites is often blocked by gatekeepers, including gang leaders and police officers, who tend to deny activities, prohibit access or frustrate interviews and observations. Outsiders, including researchers, represent a potential threat. Silence is essential to the smooth running of illegal activities.

Knowledge of illegal activities is not limited to their leaders. Many people know something about such activities, and even have crucial information about them because they usually take place through networks of social relationships which, in some cases, can involve huge numbers of actors. These actors usually do not know all the facts, but they can generally reveal some of the illegal practices concerned. In anthropological research, there are always ways to approach some of these people, gain access to their networks and gather insights without directly mentioning illegality as a research theme.

The study of illegality in daily life requires an unobtrusive and indirect approach. As part of a larger study on livelihood and social security styles, I used a bottom-up method to gather information about all sorts of economic activities engaged in by Madurese migrants in East Kalimantan. By studying the livelihood activities, insecurities and social networks of migrants, it proved possible, at the same time, to study, from the perspective of the Madurese migrants themselves, their illegal activities and their relationships with police officers. In carrying out this research it was crucial to develop good 
relationships with ordinary Madurese workers, migrants and entrepreneurs. Many such people were willing to tell me about their livelihood activities, including the 'less legal' ones, and take me to backstage areas at markets, wedding ceremonies and bars, as well as to cockfights, illegal brothels and gambling dens.

During the fieldwork, I became interested in the illegal activities in which people were involved and made further inquiries among brickmakers, and among people working in the quarries and brothels. I further investigated the key players among the brickmakers and brothel workers and carried out participant observation during cockfights, gambling and brickmaking activities. It was almost impossible to interview police officers, officials from the State Intelligence Agency (BIN, Badan Intelijen Negara) or politicians, but I managed to carry out a few informal interviews with such people without revealing the purpose of this study. In large part because of these limitations, this chapter mainly adopts a perspective on state and illegality from below, looking at the interactions through the eyes of Madurese migrants.

Many Madurese born in Kalimantan blame their negative image on newcomers, who they claim do not know how to behave, and on preman (thugs) who are members of criminal gangs and often involved in illegal logging, in running brothels and gambling dens and in smuggling consumer goods. According to those born in Kalimantan, these people cast a slur on the whole Madurese community.

\section{Relationships with Police Officers}

An element of the negative stereotyping of Madurese in Samarinda is that whenever a theft takes place, local Madurese are typically amongst the earliest to be blamed. This stereotyping makes it hard for Madurese to establish new businesses or to expand their existing ones. However, their disadvantaged status as migrants in the lower echelons of society also confers an advantage: they have more room to manoeuvre in the illegal sectors of the economy. To protect their position on the margins, many Madurese entrepreneurs maintain regular contacts with police officers, who protect their businesses and provide them with informal permission for illegal activities.

For the police, marginalized Madurese entrepreneurs are also attractive partners because, through them, the police gain access to lucrative illegal activities. Moreover, the entrepreneurs are willing to do the 'dirty' jobs which the police cannot do themselves. Examples include running semi-legal stone quarries and excavations of clay for the brick industry, running brothels, 
organizing cockfights and other forms of gambling, running protection rackets and even engaging in petty crime such as pickpocketing, organizing pyramid games and stealing. For such activities, the participants need to pay regular premiums to the police officers who routinely visit them. These premiums range from five to twenty per cent of the takings for brick, stone and transport businesses operating without licences, to over $50 \%$ for the most illegal and criminal activities such as running brothels or organizing large gambling games. According to some of my Madurese informants, at least when it comes to the small-scale activities, police officers tend to 'look after' specific sectors or businesses, which they do not always reveal to their colleagues, in order to secure a higher gain.

Moreover, Madurese, as a feared and reviled minority group, can be used by security personnel for dirty political games involving intimidation and competition between political rivals or interest groups. Many Madurese preman used to be involved in such activities in the 1980 s and 1990s but the violence against Madurese in West and Central Kalimantan from 1997 on made the Madurese more politically vulnerable in East Kalimantan, weakening their role as a political tool to be used in gang fights and protection rackets. Active Madurese involvement in the intimidation of business or political groups has declined in recent years. Nevertheless, many Madurese are still employed as security guards including in gambling dens, bars, discotheques and brothels. Good relationships with the police are needed to maintain these positions since, if relations with the police are poor, the Madurese are the first to be punished.

By not engaging directly in illegal activities, the police remain removed from direct responsibility for those illegal activities, but can share in the profits they generate. The ordinary police officers who collect a share of the proceeds from petty illegality pay, in turn, part of these proceeds to their superiors within the police apparatus. The downside of this process for the Madurese population at large is that the Madurese who engage in these mutually beneficial relationships with the police, by participating in the visible elements of illegality, reproduce the negative public image of the Madurese as a group.

\section{Community Ideas on Illegality}

Internally, the Madurese community does not tolerate every activity. On the contrary, most Madurese are proud of their community and are religiously orthodox. They clearly distinguish between licit and illicit behaviour in 
business. For instance, 'bad' behaviour includes involvement in drinking, prostitution and gambling. Involving Madurese women in prostitution, no matter how bad their reputation may already be, is perceived as a humiliation for the community as a whole and is severely sanctioned. ${ }^{5}$

Stealing and cheating customers (for example by not repaying debts, delivering lower quantity or quality of goods than ordered, or taking cash advances and never delivering orders at all) are viewed less severely provided other Madurese are not the target and nobody gets hurt. Many Madurese men retell stories of their own feats in cheating and stealing over and over again, and doing so helps to build one's status as a 'daredevil', and shows one's strength and cleverness. Nevertheless, no matter how much money is earned by such activities, the profit is generally perceived as being 'haram' (unclean, forbidden) and cannot be used for Islamic goals such as paying Islamic tax (zakat) and making donations to build mosques nor, at least according to some purists, for household needs. Many Madurese say such profits are uang panas, "hot money' that will disappear as quickly as it came. Some women told me they would not accept money from their husbands that they knew to be haram, even if they badly needed it for the household. As a result, men often buy clothes, food or presents with such money, and give goods rather than money to their wives.

At Idhul Fitri, the festivities that follow the fasting month, I witnessed the youngest son of Haji Yusuf visiting his father's home. ${ }^{6}$ Family members had seldom mentioned this son in my regular chats with them as he is a habitual gambler and works as a gaming organizer and security guard for a Chinese businessman in Balikpapan. I never gained a full picture of his activities, as his father and brothers did not want to talk much about him. At the visit, he offered his poor father a few Rp 50,00o notes. However, the father, quite embarrassingly for the son I thought, rejected the money and ignored his son completely. Later, Haji Yusuf explained to me that he did not want to take this money as it was probably earned from haram activities. Later, however, at the back of the house when I was collecting my motorbike to leave, Yusuf's wife

5 Remarkably, Madurese-speaking prostitutes from the island of Java, especially from the areas of Pasuruan, Lumayang, Besuki, Bondowoso, Jember and Sitobondo, are permitted to work in Madurese-run brothels in East Kalimantan. They are generally considered to be outsiders by members of the local Madurese community who come from the island of Madura. A rapid survey among owners of brothels shows that these Madurese-speaking women from East Java form the largest group of prostitutes in Samarinda.

6 Hajji Yusuf is a close friend of Hajji Romli, one of the cases presented later in this chapter. Hajji Yusuf used to work for Hajji Romli before they went to Mecca. 
showed me proudly the money she had been given by her son. She had taken it gladly. Most likely, Haji Yusuf will never know how his wife paid for the kitchen supplies that month.

Illegality seems first and foremost to be a male matter, but women often condone their husbands' activities and play an important role in the background. They are often prominent, for instance, in money laundering, in sending profits for investing in Madura, in managing the girls in the brothels or in establishing legal enterprises to cover the illegal activities. Often they remain silent or let it pass when their husbands lose large sums of money due to gambling or fines that result from illegal activities if they have lost their police protection. The wives of men involved in illegal practices secretly save gold or cash for difficult times, act as moneylenders to other Madurese or invest in 'clean' businesses for themselves. Such side-businesses might involve investing in a local shop, trade, food stall (warung) or truck, or in cattle, land or a house on Madura. At the same time, women often try to encourage their husbands away from criminal activities and sometimes play a crucial role in eventually converting them to a more honest lifestyle.

After achieving success in the illegal sector during their younger years, many men, typically when in their mid-thirties or early forties, have a sort of mid-life crisis. They come to see the dirty and dangerous work they are involved in as emotionally exhausting or unsustainable. Gradually, or sometimes abruptly, many men abandon their criminal activities and invest their money in cleaner business activities. They often accompany this switch with a move towards a more religious life, which they often see as a form of repentance, and which is not infrequently followed by a pilgrimage to Mecca. Such transformations are usually celebrated by Madurese friends and relatives, who view it as a move towards a better life rather than as a sign of weakness or declining power. A 'life of sin' lived during one's younger years is almost viewed as a prerequisite for becoming a true man and a genuine Muslim later. Most entrepreneurs pay a high price for their conversion, most enterprises quickly lose customers and resources, and household incomes diminish sharply. As such, a certain degree of illegality facilitates economic success, and good relationships with the police are essential for even simple businesses to run successfully.

\section{Three Life Stories}

In the remainder of this chapter, I illustrate how relationships between Madurese entrepreneurs and police work by discussing three examples. They 
are presented in ascending order of closeness with the police and with illegality. Sudi, Romli and Tamim (not their real names) have worked themselves up to become independent entrepreneurs. Sudi is a brickmaker, but without proper rights to the land he uses. He receives protection from a police officer in return for bricks or money. His good relations with the police, although costly, ensure the survival of his enterprise. They save Sudi from time-consuming bureaucratic exercises and legitimize his excavation of fertile topsoil. Moreover, his connections with the police protect Sudi against competing land claims and hostility from his neighbours. Romli, a transporter and trader of building materials, used to make a living from smuggling, theft and extortion. After ceasing these activities under police pressure, Romli fell on hard times but, through his wife and her brother, succeeded in transforming himself from a feared gang leader into a respectable community leader. Due to his good contacts with the police, he is often able to negotiate on behalf of Madurese arrested for petty crimes, reducing their fines or getting them released from police custody. In return, Romli provides intelligence to the police in cases of murder or ethnic violence. Finally, Tagil offers us a glimpse into the split life of many criminals in Indonesia: he is a gambling boss and pimp running his own illegal activities but, at the same time, he is an instrument in the hands of the police apparatus.

\section{Seeking protection: Sudi}

In 2003 and 2004, I met Sudi several times at his brick kiln, located on the back road to Bayur. When taking a rest, overseeing his workers or firing the bricks, he was always ready for long talks, and he openly shared the story of his life with me. Within five years of arriving in East Kalimantan from Madura in the mid-1980s, Sudi had become a successful organizer of cockfights and other gambling. He was feared for his aggressiveness and bad temper. Many people saw him as one of the most daring of the young Madurese 'madmen' roaming the area of Samarinda in the mid-199os. 'Everyone was afraid of me', he told me during one of our conversations. 'I could beat anyone. Be it fighting, drinking or motorbike racing, I always wanted to win. Sometimes I had loads of money in those days, but sometimes I lost large amounts and did not come home for days. In the end, I had a debt of Rp 26 million.' In one of our interviews I ventured to ask his wife, sitting towards the back of the house, but listening carefully, if she had not become angry with his behaviour, or tried to prevent him from gambling. 'Angry? What do you think? I was mad with him. But, you know, it was better to remain silent with this man. I was at home with two 
small children. If you get mad with hot-headed people like he was, they get even more angry and rough. It's better to be careful.' Sudi nods. 'I was like that. When I came home late at night and my wife did not open the door fast enough, I kicked it in.'

After a violent fight with Buginese thugs, one of whom was reported to be severely wounded or even killed, Sudi ended up in a police cell. ${ }^{7}$ One of his maternal uncles in East Kalimantan, Saïd, had good connections with the police and succeeded in buying him out, on the condition that Sudi would never again engage in crime. Saïd demanded that Sudi quit his 'bad' life of drinking, gambling and living with prostitutes, and offered him a job as foreman in his brickmaking enterprise. Saïd's good relations with the police protected Sudi from the revenge of the Bugis men and their networks. From that time onwards, life went better for Sudi.

Nine years later, Saïd sold some of his possessions in Kalimantan and went on the pilgrimage to Mecca. When he came back, he went bankrupt due to his own overspending and being cheated by his business partner. Sudi lost his job and started to gamble again. He lost millions of rupiah in the course of a few months. In an attempt to change his luck, he borrowed money from a friend and bought a cheap brick kiln in Bayur. This kiln had previously belonged to a Madurese who had been attacked and killed by an angry mob who had accused him of theft. To obtain clay, Sudi, with the help of a policeman who had been befriended by his uncle Saïd, rented land from villagers. The policeman gave money to one or two of the villagers and told them to refrain from further hostilities against Madurese. After Sudi made his first bricks, it turned out that there were multiple claims to the plot where his kiln was located and also where Sudi obtained his clay. Villagers from two neighbouring villages claimed it as their community land and protested against the commercial excavation of the soil. Moreover, they no longer wanted any Madurese living close.

Sudi called in the help of the policeman who visited regularly in that period. Word of Sudi's friendship with the policeman spread fast, and regular sightings of him at Sudi's kiln was enough to discourage villagers from protesting. According to Sudi, he also talked to the village heads. From that time on, his relations with his neighbours have been calm. 'I

7 Sudi did not tell me much about what happened to these Bugis men, and simply referred to them as 'wounded thugs'. I got some information about them from others, but the accounts were neither first hand nor unambiguous. Some spoke of one or more of Bugis thugs being killed, others of them being severely wounded. 
even visited their mosque and donated 4,0oo bricks for its renovation. But I do not fully trust them. I need my friend, the police officer. He also helped me when some Bugis men were looking for me in an attempt to reclaim a gambling debt. My friend [the police officer] gave them some of my money and told them to be silent. They never returned.' The help of the policeman-cum-friend is not without cost. At the start of their cooperation, the police officer asked for a percentage of the bricks that Sudi produced: 5,000 out of every 100,00o bricks produced. In Sudi's first year, when bricks were expensive and production still low, this amounted to 17,00o bricks, worth almost Rp 6 million. 'It was said he was busy building a house for himself.' Later, when the price of bricks fell, the police officer wanted to have Rp 500,000 for every 100,00o bricks produced. By the time of my research, Sudi had built up a large business producing about 250,000-300,000 bricks per year with about eight to ten people working for him. Still, when bricks are fired, about five or six times a year, the policeman visits Sudi and asks for money. 'I do not know where he lives, but if he comes, I give him Rp 100,000 or more if he keeps on asking. He's actually a poor guy', justifies Sudi to himself, 'He has got to give most of his money to his seniors.'

During my study of Madurese livelihoods in East Kalimantan, I encountered several enterprises such as Sudi's. The entrepreneurs involved gained access to land and sometimes even land titles by using close connections with the police. Some of them received direct police protection in the event of land conflicts, hostility or problems with creditors. In 7 cases out of 118 in my sample, entrepreneurs told me explicitly, and in detail and without prompting, about their relationships with the police: about the payments they made and the percentages taken. In another five cases businesspeople informed me about similar relationships but with less detail. ${ }^{8}$ Two-thirds of these twelve cases were brickmaking enterprises, while most of the others were remote quarries where stones were cut for road construction.

The labourers in the quarries are predominantly workers from Sampang who, for one reason or another, prefer to work in faraway places. Some of them are refugees from ethnic violence in West and Central Kalimantan, others are migrants with a dubious legal status because they lack local identity permits

8 I could not inquire directly about relationships with the police in all the interviews with entrepreneurs. Sometimes, I thought that discussing these relationships would be considered inappropriate and, in some of my early interviews, the topic had yet to seem important. 
(КTP). Others have problems such as unpaid debts, criminal charges or accusations of extra-marital relationships hanging over their heads. They often mention threats of a revenge killing (carok) as a reason for working in remote places. These quarries are located in the hills and in largely uninhabited areas $5^{-20}$ kilometres from the city. In the quarries, individual police officers provide protection in return for a percentage of the price earned for all the truckloads of stones that leave. They come to visit every week and sometimes bring basic supplies such as drinking water, salt, soap or rice. In the quarries, policemen are paid commissions of up to $15 \%$ of the value of the stone produced there. Percentages in the brick kilns seem to be generally lower and I did not hear of any 'commissions' higher than five percent in the brick industry. I suspect that percentages at the quarries are higher because the people there are more vulnerable and the money covers personal protection as well as business protection.

Nevertheless, it seems money well spent. In the case of Sudi, these premiums protected the enterprise against legal claims by neighbouring villagers and freed him from hassles with old enemies. Unlike in some other cases, where police officers turned out to be unreliable or incapable of helping out, his relationship with a specific police officer yielded results. It has ensured continued access to resources and the sustainability of the family business. Five to fifteen per cent seems a not unusual fee for a migrant to pay for success. Premiums depend on the kind of business, the level of illegality and the tolerance shown by senior police officers. Sometimes the control exerted and the demands of police officers are larger.

Squeezed loyalties: Romli

Hajji Romli lives on one of the main roads connecting Samarinda to the hinterland of East Kalimantan. With his white peci hat and grey beard, it is difficult to guess his age, but his black eyes stare with great intensity. He talks fast and asks direct questions. With his wife, he runs a successful distribution centre, crammed with building materials such as sand, bricks, stone, cement and timber. Since 2006, he has also operated as a subcontractor doing the rough construction work in large projects won by large contractors. In large projects tendered by other players, Romli takes care of the supplies, the groundwork, the foundations and sometimes the construction of brick walls, sewage systems and roads. Other subcontractors take care of the wood, metal and roofing work and other skilled tasks. Romli also tenders directly for smaller projects, such as public buildings, small roads, drains and the like. The trade and contracting 
business are essentially his, but his wife organizes the transportation side. She owns four trucks and an excavator. Romli usually uses two of these trucks if he has construction orders: 'I only take large orders such as for houses, blocks or shops, otherwise I do not make a profit. If there is a lot of work, I will send for more labourers from Java and use trucks from fellow Madurese businesses.'

As my research progressed, I slowly discovered how important Romli was as an informal leader in the Madurese community, and as a broker in relations with the police. He negotiates bribes when Madurese are arrested for petty crimes or taken into custody following traffic accidents. He supports Madurese who are occupying land that is claimed by others, and he mediates in property conflicts. He takes parts in tendering for projects. He was also involved in peace negotiations during ethnic tensions in 2005 and $2007 . .^{9}$ In return for his loyalty to East Kalimantan's elites, he has been granted excavation concessions in the rocky hills of Batu Besaung and is able to acquire construction projects. Whenever ethnic tensions rise in Samarinda or its vicinity, he is called upon by the town mayor, members of the East Kalimantan parliament, or the head of the police or of the military to prevent Madurese from engaging in violence. He is regarded as influential among the Madurese and loyal to the interests of the ruling elites who prefer stability. ${ }^{10}$ During our conversations, it seemed that Madurese people almost continuously entered the house to ask for advice, to borrow money or to discuss matters of political interest. The almost constant beeps and rings from his several cell phones also illustrated the extent of his social network.

Before all this, in the 1970s and 1980s, Romli used to be a notorious gang leader and gambler in Samarinda. His wife saved some of the profits and, at the end of the 1980s, she bought a truck to rent out and use to transport construction materials. In those years, Romli was involved both in simple theft and in swindles that involved goods that were never delivered and loans that were never paid back. He also organized large-scale

The 2005 negotiations, which were initiated by East Kalimantan's security forces, are briefly described in De Jonge and Nooteboom (2006: 470-471). At the end of 2005, tensions rose between Dayak and Madurese in Samarinda due to the stabbing of the son of a Dayak adat leader and the deaths of two Madurese. Romli was invited to the security meetings and was able to calm Madurese groups who called for revenge. This increased his political influence and improved his contacts with high-ranking security officials. 
gambling frauds. However, he is quick to point out that 'we did not steal from our friends and fellow Madurese.' It is also said that he was involved in the killing of several Bugis rivals, but he always remains vague on this point. Nevertheless, these rumours add to his reputation for toughness. To this day, any Madurese who killed Bugis gang leaders in those diffiicult years still retain a lot of respect among members of the Madurese community.

'In the 1980s, it was not safe in Samarinda', Hajji Romli recalls quietly. Then he reached a turning point: 'I lived a bad life and almost daily we had fights at the market. I was clever enough never to be caught and I had many friends in the police who informed me when activities were getting too hot. One day, a high-ranking police officer came to my house and asked me to stop stealing and to help them fight criminality. If I declined, I would be the first Madurese to be taken to prison, they said. I could not do anything but obey. Moreover, deep inside of me, I already knew the things I was doing were wrong. I longed to live a better life.'

From that time onwards, Romli stepped down as a gang leader and ceased stealing. 'I also no longer fought, and tried to prevent my people from gambling', he adds. 'I was regularly asked by police officers to 'convert' certain hotheads and criminals who were fighting and making trouble at the market. I had to turn them into hardworking people, which I did through offering jobs. The police would allow me to continue to organize gambling, but they asked for some of the profit.'

It was only after Romli went on a pilgrimage to Mecca that his gambling activities stopped. Hajji Yusuf told me once that Hajji Romli had persuaded him to go to Mecca. 'He even provided part of the money for me', Yusuf said. 'However, we could not quit our habits at first. While waiting at the airport, we continued to gamble for money. Only after our return from the holy land, did we stop gambling for money. Now we use 'penalties' which do not involve money such as drawing something on someones face or hanging batteries at someone's ears.'

In the meantime, his wife bought a second truck and due to an increasing demand for construction materials, business expanded and Romli offered work to a number of his former gang members. Not everyone accepted his change to a regular lifestyle. Many of his former followers continued their previous criminal activities, others joined different gangs or started businesses of their own. "The majority remained loyal to me and, after some time, I could persuade them to start working for me.' Eventually, the police caught most of the notorious thieves from his group. 'I was a good leader and bought them out of the prison.' He smiles 
self-confidently when he says this: 'it was a good investment. They are now my most loyal workers...And, I got some good friends in the police, which is important.'

\section{Living dangerously: Tagil}

Tagil's activities are much more dangerous. Tagil is a notorious gambler, and also a known preman, gang leader, organizer of cockfights and operator of a large bar-cum-brothel in Damanhuri, a prostitution compound on the edge of Samarinda. 30 to 40 women and girls work in this brothel. Most of them come from mainland East Java and roughly half speak Madurese. None of them originate from the island of Madura itself according to Tagil: 'We would never permit Madurese women to do this. It would make us ashamed. She would be killed.'

On Saturdays and Sundays, Tagil organizes cockfights on the outskirts of Samarinda. Two to three hundred people participate during these fights, and large bets are taken. Most are Madurese and Bugis, but also Chinese, Banjar, Javanese, Dayak and Butonese attend. The stakes are high. Especially the Chinese and Bugis, but also sometimes Madurese, can bet large amounts. On days like Christmas and New Year, stakes can amount to tens of millions of rupiah per fight. At the same time, spectators bet with smaller amounts ranging from $\mathrm{Rp} \mathrm{50,000}$ to $\mathrm{Rp}$ 500,000. From each fight, the winner pays $10 \%$ to Tagil who, for his part, pays half of this to policemen who are unofficially present in the arena and to higher ranked police officers. Tagil also earns money from the entrance fee of $\mathrm{Rp}$ 5,00o paid by each spectator, and from other gambling activities that take place at the site, such as Cap Ceki, card and dice games, and from the rents collected from the dozens of ordinary vendors there. The rents range from $\mathrm{Rp} 10,000$ per day for a cigarette seller to 50,000 for a fully equipped food stall offering several kinds of food and drinks.

Tensions around the cockfights get so heated that Tagil's gang members sometimes need to restore order. If they are unable to do so, the undercover policemen who are present intervene by shooting in the air, arresting people or even randomly shooting some of the fighters in the leg or knee. With payments, and mediation provided by Tagil, the arrested gamblers can be freed. The usual fees for the police in such a case depend on the status of the captured person and the severity of the offence, and range from Rp 5 million to Rp 15 million. The ties between Tagil and the police who attend his cockfights are close. They regularly visit each other at home, or go out to eat or drink together. Police officers are also said to visit his brothel. 
In one of my visits, Tagil told me how, in the early 1980s, he was hunted by the police for having murdered a competing Bugis gang member. 'I fled to Madura to a place where they would never find me. After a few years, a distant relative of mine succeeded, after making large payments, to erase my name from the police archives. The police officer at that time urged me never to commit murder again and asked if I wanted to help with searching for criminals who had fled to Java. That's what I did and I still sometimes do. I have become quite good at it. Last year, we tracked down a lad in Malang who had raped a girl here and run away to Java.'

But things are not as secure as Tagil made out when I met him that time. 'The police are asking for more and more money all the time', he complained in a confident moment later in 2004. 'The work is dangerous and I cannot do business with the new chief commissioner. I would prefer to retire and move to Java. But I am obliged to keep in touch with them. It's like a forced marriage.' He hopes to be able to save enough money for a quiet retirement. In his home village in Madura, he is no longer welcome. 'They don't want to take my money there anymore. It's haram, they say, unclean.'

A few months after this talk, in early 2005, Tagil was sent to prison by the new chief of the police who accused him of verbally abusing the governor of East Kalimantan. At a meeting with high ranking officials, Tagil had argued against the closure of the Damanhuri complex during Ramadan and accused the governor of being inconsistent because some complexes remained open, while others had to close. The governor took offence. Other people subsequently told me that Tagil's business had in fact been declining for some time, as he had been unable to deliver sufficient funds to the police. The new chief of police demanded more money than Tagil wanted or could pay. Remarkably, the Damanhuri complex did not close during Ramadan that year and Tagil continued to run his activities from within prison.

Three months later, Tagil was freed after paying large sums of money. Some people say that one or two of his uncles, large entrepreneurs with good connections with the governor, paid to free him. The uncles told me that they helped Tagil a bit so that he could succeed in business. 'This is just a family obligation', they said. By 2006, Tagil had joined a new business of his uncles. They had just acquired a badly managed coal concession and started to excavate, with the backing of influential police officers and politicians, in areas contested by other claimants. In 2008, Tagil and his uncles were busy supporting candidates for the provincial elections. One uncle expressed an ambition of a political career for himself. The 
fact that their business is risky and legally dubious does not prevent them becoming involved in politics, in fact it makes political connections and protection all the more important.

\section{Conclusions: Out of Wedlock}

Migrant Madurese entrepreneurs in East Kalimantan face numerous obstacles in making their enterprises work. Brickmakers face difficulties in obtaining land rights and cheap firewood, transport entrepreneurs face insecurities in obtaining transport licences, and workers in stone quarries need protection against exploitative middlemen and insecure contracts. Moreover, Madurese migrants are not among the most favoured ethnic groups in East Kalimantan and sometimes face severe discrimination and hostility. This is not always for unjustifiable reasons, as some Madurese migrants are, or have been, involved in illegal and illicit activities such as organizing cockfights, gambling, theft, gang fights and running prostitution rackets. Madurese entrepreneurs and preman involved in such illegal activities find it essential to maintain good relationships with police officers, generally low-ranking ones, for protection and to keep their activities running. They maintain these relationships with police officers through regular visits and payments of either irregular sums or fixed shares of the profit from the businesses concerned.

If we invert our perspective for a moment, it becomes immediately apparent that the relationships with Madurese migrants are also beneficial for the police. Besides generating additional income, these relationships offer the police access to an otherwise closed migrant community and helps them to control that community. ${ }^{11}$ In the event of increased ethnic tensions or unacceptable rises in crime, the police use their contacts with entrepreneurs, preman and ethnic leaders who depend on them for business success. These same contacts can then be used to help control their own community and fight criminality. These individuals might provide the police with information, they may utilize their own networks to try to calm social tensions, or to curb the activities of particular members of the community and, in extreme cases, they might even detain aberrant members of the community and hand them over to the police.

11 The strategy is similar to one used by the army's special forces (Kopassus) which frequently recruit criminals to use in counter-insurgency campaigns: Liem Soei Liong (2002: 202). 
These examples show that the mutual dependence of Madurese entrepreneurs and police officers not only provides direct financial and other benefits to both parties involved, but also sometimes serves a higher goal of maintaining security and stability for society at large. It is ironic that this social control is only made possible by allowing criminality and instability to exist at an 'agreed' level.

In the illustrated cases of Sudi, Romli and Tagil it is difficult to demarcate precisely where the border between legality and illegality lies. However, doing so is also not necessary: the twilight zone between legal and illegal activities offers Madurese entrepreneurs and the police many financial and political opportunities. The police offer migrants protection and, in return, get a share of the profits generated by illegal activities. At the same time, the police make no promises to tolerate all forms of criminality. On the contrary, they can use their connections with gang leaders to help fight crime. They get to control the underworld by a combination of taxation and repression. At the same time, they also get a steady income from illegal activities.

Bribes, commissions and the profits of illegal activities lower the transaction costs for disadvantaged groups who cannot, or do not know how to, navigate the road of formal and legal economic activities. Without the payments and commissions, it would probably be much more difficult for Madurese to sustain their economic activities. At the same time, one should not forget that the police are also dependent on the entrepreneurs. Police officers are poorly paid in Indonesia but face high expectations in their social environment (from friends, family members, neighbours and so on) that they will maintain a comfortable lifestyle and provide help when it is needed; they also face demands for payments from their superiors within the police apparatus. In short, there is a successful and mutually beneficial 'marriage' between entrepreneurs and police officers. The intimacy of the marriage makes it unlikely that there will be an early victory in Indonesia's repeatedly proclaimed war on corruption.

This marriage is, however, often not based on love. Just as some marriages involve a certain amount of discretion and even deliberate blindness, the relationship between the police and Madurese businesspeople and criminals in East Kalimantan is also based on a sort of paradox. The police in Samarinda need to permit a certain level of criminality in order to keep criminality under control. By permitting some forms of 'petty' criminality (such as pickpocketing, stealing, cheating, gambling, prostitution) - activities which are detested by the community, but which can be dealt with by mobs through lynching and public justice - they are able to gain access to and control over the worst forms of organized crime (such as killings, gang fights, gang rapes, 
car thefts) and even ethnic violence. They do this by mingling with and engaging in the networks of criminal groups.

This world of petty criminality, at least in East Kalimantan, involves collaboration between police and small entrepreneurs, and the regular payment of small fees $\left(5^{-15} \%\right.$ of turnover). The payments are essential to the smooth functioning of the system, a system that is based on personal contacts and offers an alternative to a properly functioning Weberian taxation and policing system. It can thus be argued that the state in Indonesia needs to be involved in illegality in order to be able to control criminality: and that state officials have been relatively successful in this. From a citizen's perspective, Indonesia is a relatively safe country. In most Indonesian cities, people are not in constant fear of being robbed, killed or raped. Where justice falls short, the police leaves the mob sufficient space to take revenge. A premium of 5 to $15 \%$ is a much lower sum for security than the taxes most people pay in countries relatively free of corruption. As such illegality is not only destructive, it can also help to sustain order in society. 